Aquaculture

October 2015, Volume 447, Pages 44-55

http://dx.doi.org/10.1016/j.aquaculture.2015.02.009

http://archimer.ifremer.fr/doc/00252/36301/

(C) 2015 Elsevier B.V. All rights reserved

\title{
A revolution without people? Closing the people-policy gap in aquaculture development
}

\author{
Krause Gesche ${ }^{1,2}{ }^{*}$, Brugere Cecile ${ }^{3}$, Diedrich Amy ${ }^{4,5}$, Ebeling Michael W. ${ }^{6,7}$, \\ Ferse Sebastian C.A. ${ }^{8}$, Mikkelsen Eirik ${ }^{9}$, Perez Agundez José A. ${ }^{10}$, Stead Selina M. ${ }^{11}$, \\ Stybel Nardine ${ }^{12}$, Troell Max ${ }^{13}$
}

${ }^{1}$ Alfred Wegener Institute Helmholtz Centre for Polar and Marine Research, Am Handelshafen 12, 27570 Bremerhaven, Germany

${ }^{2}$ SeaKult Consulting, sustainable futures in the marine realm, Sandfahrel 12, 27572 Bremerhaven, Germany

${ }^{3}$ Stockholm Environment Institute, University of York, Heslington, York, YO10 5DX, United Kingdom

${ }^{4}$ SOCIB, ParcBIT, Ed Naorte, Ctra. Valldemossa, km 7,4, 07121 Palma de Mallorca, Balearic Islands, Spain

${ }^{5}$ College of Marine and Environmental Sciences, James Cook University, Townsville, Queensland 4811 ,

Australia

${ }^{6}$ Thünen-Institute for Sea Fisheries, Palmaille 9, 22767 Hamburg, Germany

${ }^{7}$ University of Applied Sciences Bremen, Werderstraße 73, 28199 Bremen, Germany

${ }^{8}$ Leibniz Center for Tropical Marine Ecology, Fahrenheitstr. 6, 28359 Bremen, Germany

${ }^{9}$ Norut, Northern Research Institute Tromsø, PB 6434 Forskningsparken, 9291 Tromsø, Norway

${ }^{10}$ Ifremer - UMR-Amure/Marine Economics Unit, ZI de la pointe dudiable, CS 10070, 29280 Plouzane, France

${ }^{11}$ School of Marine Science and Technology, Newcastle University, Ridley Building, Newcastle upon Tyne,

NE1 7RU, United Kingdom

${ }^{12}$ EUCC - The Coastal Union Germany, Seestr, 15, 18119 Rostock, Germany

${ }^{13}$ The Beijer Institute for Ecological Economics, Box 50005, 10405 Stockholm, Sweden; Stockholm Resilience Centre, Stockholm University, Sweden

* Corresponding author : Gesche Krause, Tel.: + 494714831 1631, + 4947177504 ; email addresses :

gesche.krause@awi.de ; gesche.krause@seakult.de

cecile.brugere@sei-international.org ; amy.diedrich@jcu.edu.au ; Michael.Ebeling@ti.bund.de ;

sebastian.ferse@zmt-bremen.de ; eirik.mikkelsen@norut.no ; Jose.perez@ifremer.fr ;

selina.stead@ncl.ac.uk ; stybel@eucc-d.de ; max.troell@beijer.kva.se

\section{Highlights}

- addresses the socio-economic impacts of aquaculture - identifies why there is the gap in available knowledge and policies identifying the role of framing conditions for aquaculture development development of multi-dimensional assessment framework

Keywords : Aquaculture, socio-economic assessment, human dimensions, integrated analysis framework, participation 


\title{
A Revolution Without People? Closing the People-Policy Gap in Aquaculture Development
}

\author{
Gesche Krause $^{1 a_{*}, b}$, Cecile Brugere ${ }^{2}$, Amy Diedrich $^{3 a, b \dagger}$, Michael W. Ebeling ${ }^{4 a, b}$, Sebastian C.A. Ferse ${ }^{5}$, Eirik \\ Mikkelsen ${ }^{6}$, José Perez Agúndez ${ }^{7}$, Selina M. Stead ${ }^{8}$, Nardine Stybel ${ }^{9}$, Max Troell ${ }^{10}$
}

\section{Introduction}

A notable disconnect between science and policy in relation to aquaculture development exists (Costa-Pierce, 2010; Kaiser and Stead, 2002; Stead, 2005). Many have argued that, in order to bridge this 'science-policy gap', synthesizing multidisciplinary knowledge about complex issues affecting policy decisions is a necessary part of an integrated planning process (Bradshaw and Borchers, 2000; Dürrenberger et al., 1999; Fischhoff, 2012; Jones et al., 1999; Lubchenco, 1998). However, assumptions about origins of the science-policy nexus hold direct implications for how this interface is managed (Graffy, 2008) and is heavily influenced by social, economic, political and cultural conditions (Ahmed, M.,\& Lorica, M., 2002; Sinh et al., 2007; MacNeil et al., 2010; Beveridge et al. 2013). In the case of aquaculture, a contextual approach particularly in terms of the social impacts of aquaculture at different scales (individual, community, national, regional and international) has been neglected. Indeed, the ongoing rapid spread and evolution of aquaculture dubbed the "blue revolution" is still in its infancy with respect to addressing the issue of how to design and implement processes to support management informed by those with relevant interests for translation into policy. This participatory process seeks to integrate lay persons' (citizens, stakeholders) views and knowledge with scientific information and procedural rationalities, to adapt to new issues and needs, and to plan and implement effective responses.

More often than not, the local socio-economic implications of aquaculture development are taking a back seat to trade, ecological and technological motivations, especially in light of current efforts towards sustainable intensification of aquaculture production (Smith et al., 2010). This is worrying, since the bulk of aquaculture production is produced in developing countries in which smallholders dominate the rural landscape, making up a large proportion of people involved in aquaculture production in many countries. They participate across the wide spectrum of aquaculture, ranging from subsistence fish farming to specialisation in more commercially oriented forms of aquaculture (WorldFish, 2011). If the potential socio-economic costs and benefits of aquaculture continues unchecked and not considered as part of aquaculture policy development, the result is the exclusion of society from a revolution initiated for its very own benefit. This could result in social and environmental repercussions counterproductive to aquaculture's potential to addressing global food security issues.

Currently, governments and international organizations (e.g. FAO, EU) worldwide are responding to the blue revolution by becoming increasingly interested in expanding aquaculture to foster food security, nutrition and income generation. Scientific and technological advances have underpinned the onset of this blue revolution and are increasingly informing aquaculture development policies (e.g. SCAR-Fish, 2013) meaning that biological, economic and

\footnotetext{
* Corresponding author (gesche.krause@awi.de)

${ }^{\dagger}$ Current address
} 
technological concepts have found their way into high-level decisions. Reports such as the "Blue Frontiers" by Hall et al. 2011 that aim to inform policy makers about the impacts of aquaculture on the environment and to stimulate debate on the optional animal food production systems for tomorrow are a case in point. However, despite these commendable efforts, we argue that aquaculture has not yet reached its potential largely because, to-date, there has been little attempt to manage this sector's activity by taking into account its multiple and varied dimensions (social, ecological, economic). Instead, the focus has been production-oriented. Furthermore, most research has focused on species exported from, and areas exporting to, the developed countries rather than on the more significant production, trade and consumption that occurs in most developing countries, indicating a severe social scientific knowledge deficit in aquaculture research (Belton and Bush, 2014). In addition, 95\% of the global food economy is domestic and just $5 \%$ is trade, with the result that 'what happens in urban markets and in urban-rural supply chains is by far the most important market force affecting farmers' (Reardon, 2012; Belton and Bush, 2014). This underlines the placed-based and highly social-contextual nature of aquaculture production and the importance of the social construction of knowledge pertaining to certain aspects of aquaculture.

In order to be effective and inclusive, decision-making and policy formulating processes should be informed by science (where relevant) and include input from stakeholders at various levels of decision-making (e.g., individual, local, national and regional). With increasing transparency being demanded about decision-making then policy makers, for example a scientific fisheries officer working in a government natural resources management department, are under pressure to show what evidence they are using to base decisions on management measures selected. Policymaking institutions can vary depending on the country and evidence for policy making coming from members in the government administration to other international and semi-private organizations such as the Food and Agriculture Organization of the United Nations (FAO), the World Wide Fund For Nature (WWF) and Aquaculture Certification Council (ACC), etc., all of which are interlinked by formal and informal institutional exchange processes. In this sense, institutions can be termed as rules of the game (North, 1990) which are the interface, regulating what members of the social systems (or local stakeholders) are permitted and forbidden to do in relation to the ecological systems and in relation to themselves (Ostrom, 2005, Schlüter et al., 2013). Social Network Analysis can shed light on how these different institutions interact and exchange information that can be used as evidence in policy-making (Turner et al., 2014).

Thus, we argue that the failure to address the social sustainability of aquaculture is further exacerbated in many countries by a lack of participation by, and consideration of, a wider range of stakeholders in the decision-making and policy-formulating processes surrounding implementation of aquaculture (e.g., the certification process for Pangasius in Asia; Belton et al., 2011). Further, in the light of globally growing urban middle classes and marginalised rural communities, especially in the developing countries (Belton and Bush 2014, Hall et al. 2011), questions concerning property ownership, labour utilization, relations of production and the role of the state are timely (Belton et al., 2011; Davis and Ruddle, 2012; Ruddle and Davis, 2013; Lan 2013) and ideally should be included in policy-making when impacts of particular management measures are being considered. In many parts of the world, people are affected differently by such institutional arrangements and academic interests, thus policy directions may not necessarily reflect their concerns, priorities or necessities, leading to the question of which type of aquaculture and for whom (Belton and Little, 2008; Belton and Little, 2011; Toufique and Belton, 2014). Furthermore, socio-economic drivers influence human behavior thus taking 
account of the former when considering impacts of management measures recommended by policy can lead to selection of actions more likely to be beneficial to managing aquaculture sustainably. To achieve this we argue people need to be part of the decision-making process about aquaculture development.

This article addresses the implications of and possible solutions to the omission of people in the aquaculture decision and policy development process; a phenomenon we refer to as the "peoplepolicy gap". By people, we are referring not only to the operators and workers in the industry, but also communities in the vicinity (or at distance) of production facilities, who are directly or indirectly affect by aquaculture. The "gap" pertains especially to the inclusion of local knowledge, norms and rules in use and the contextual stakes people face in everyday decisionmaking and production. This gap is further widened by the lack of socio-economic considerations in research related to aquaculture development, neglected in favour of aspects pertaining how resources and ecological system functions are impacted, thus receiving priority in a profit-driven privately dominated sector. Davis and Ruddle (2012) have argued for small-scale fisheries that co-management approaches ostensibly meant to improve the well-being of impoverished and marginalized coastal dwellers have instead reinforced existing inequalities and further contributed to the accumulation of wealth by powerful elites because fundamental assumptions about policy and intentions of the state have not been addressed. Béné (2005) observes that the debate on shrimp aquaculture development has shifted from a critical political ecology discourse in the 1990s that was concerned with social sustainability and questions of power to a more technocratic 'best management practice' discourse that neglects the political dimensions of aquaculture expansion. Hence, while the science-policy gap, which hinders the effective translation of science into policy, has received increasing (and justified) attention in recent years, a people-policy gap still exists in many places. Due to social consequences such as a lack of support for aquaculture production, the latter can result in development that fails to address the concerns of a large part of affected stakeholders. This has partly been exacerbated by unclear guidance on how best to integrate socio-economic factors impacting aquaculture development when formulating policy to support sustainable growth of the sector. We postulate herein that this constitutes a larger threat to sustainable aquaculture development than the lack of knowledge and 'science' about the activity.

\section{The Growing Importance of Aquaculture}

Today, seafood and seafood products are the most traded global food commodities and the proportion of harvested (and cultured) fish being internationally traded has steadily risen from 8 million tons (25\%) in 1976 to 58 million tons (37\%) in 2012 (FAO, 2014a). Around 1.25 billion $\left(10^{9}\right)$ people worldwide rely on fish as their primary source of animal protein, and 4.3 billion people derive at least 15\% of their animal protein intake from it (FAO, 2012a). This share varies from country to country: Sierra Leone $72 \%$, Ghana 55\%, Maldives 70\%, Bangladesh 57\% and Indonesia $54 \%$, reflecting a high dependency on fish and fishery products of the total percentage of animal protein intake in these countries.

Although it is difficult to obtain accurate data, estimates indicate that the livelihoods of 660-820 million peoples are linked directly and indirectly to fisheries and aquaculture (FAO, 2012a). More than $95 \%$ of the fishers and aquatic farmers worldwide are employed in the developing or emerging countries (Williams et al., 2005), stressing the important role aquaculture plays in terms of food security and livelihoods. With global changes in consumption patterns and population 
growth, continued growth in aquaculture production is expected to be an important part of the solution to meet global food demand (Cressey, 2009; Williams et al., 2000; Troell et al. 2014).

Indeed, aquaculture is becoming increasingly important in a number of ways. In 2012 it provided $49 \%$ of the world's total fisheries and aquaculture production of 182 million tonnes live weight equivalent, according to FAO statistics ${ }^{1}$. The first-hand value of the aquaculture products was US\$ 144.4 billion, where US\$ 137.7 billion was generated by 67 million tonnes of fish, crustaceans and molluscs while US\$ 6.4 billion through 24 million tons of aquatic plants.

The same statistics show that aquaculture production increased more than five-fold from 1990 to 2012, while world capture fisheries increased with only $8 \%$ over the same period of time. Moreover, between 2000 and 2012 capture fisheries production declined. In contrast, aquaculture production increased on all continents, but most noteworthy in Asia. Despite the tremendous global growth in aquaculture production since 1990, Asia increased its share of world's total production from $86 \%$ to $91 \%$. Since 2008, the majority of Asia's food fish products stems from aquaculture. China is by far the largest aquaculture country in the world, with a production of about 41 million tonnes of fish and 13 million tons of aquatic plants in 2012 (FAO, 2014).

Generally, the importance of the fisheries sector to employment (measured as percentage of fisherfolk in the economically active population) differs a lot from country to country. It is particular high in small island states like Samoa, Solomon Islands, Comoros but also very important in countries with a large population like Indonesia, Chad, Philippines, Ghana, Vietnam, Bangladesh, China and India (FAO 2013). According to FAO (2014), employment statistics do not include those working in fish farming in inland waters, but since inland waters provide nearly half of the volume in global aquaculture (FAO statistics), employment there is also substantial. Indeed, in the period 1990-2012, employment in the broad fisheries sector has grown faster than the world's population, and faster than employment in the agriculture sector (FAO, 2014).

Within the broader fisheries sector, aquaculture employment rates grew even faster, increasing its share within from 17 to $32 \%$. In this context, it is estimated that nearly 1 out of 6 people employed in the fisheries primary sector in 2012 were women. However, women mainly dominate in secondary activities of this sector, such as processing and packaging, making up as many as 9 out of 10 persons employed there (FAO, 2014). However, the average production per person employed in aquaculture varies a lot between regions, from around 3 tons per year/per person in Asia, 5 tons per year/per person in Africa, 10 tons per year/per person in Latin-America and the Caribbean, 28 tons per year/per person in Europe, and up to 59 tons per year and person in North-America (FAO 2014). In contrast, for instance in Norway the average production per person in fish farming was 195 tons in 2011 (op cit.) These differences reflect variances in capital inputs, industrialisation of production, livelihood, and typically in income per capita.

\section{The Inclusion of Social Stakes in Aquaculture}

To date, aquaculture development has been largely focused on technical and biological challenges (Costa-Pierce, 2010) and less on the socio-economic drivers underpinning peoples'

\footnotetext{
${ }^{1}$ From

http://www.fao.org/figis/servlet/TabLandArea?tb ds=Production\&tb mode=TABLE\&tb act=SELECT\&tb grp=COU NTRY\&lang=en, accessed 9 September 2014.
} 
behaviour. Most socio-economic analysis deals mainly with the effects of salmon or shrimp farming, and to a lesser extent with e.g. Pangasius and Tilapia, as well as filter feeders (such as Crassostrea gigas) and seaweeds (such as Kappaphycus alvarezii and $K$. striatum as well as Eucheuma denticulatum) (see Buanes et al., 2004; Barton and Fløysand, 2010; Fröcklin et al., 2012; Stonich and Bailey, 2000; Joyce and Satterfield, 2010; Sievanen et al., 2005; Buchholz et al., 2012).

However, questions pertaining to the inter-relationships between community impacts, right of access, ownership, taxation, liabilities for the negative repercussions from the environmental effects on society, and ethical issues, to name but a few, have remained largely un-tackled in a comprehensive, integrated manner. As a result, the socio-economic consequences of aquaculture operations are often poorly understood and repercussions such as poaching not fully anticipated (see examples given in Barret et al., 2002; Bunting, 2004; Fröcklin et al., 2012; Isaksen and Mikkelsen, 2012; Jentoft and Chuenpagdee, 2013; Sandberg, 2003; Sievanen et al., 2005; Varela, 2001). In many cases the omission of relevant stakeholders and social concerns in aquaculture development projects has contributed to inequity, social conflicts and violence (Martinez-Alier, 2001; Nagarajan and Thiyageasan, 2006; Varela, 2001). The unavoidability of feedback between largely structural and technical interventions and the socio-economic systems, within which they are embedded, highlights the need for employing more systematic (or ecosystem) approaches to analyse cause and effect relationships and to explore future sustainable, efficient and equitable development scenarios (Hopkins et al., 2011; Belton and Bush, 2013).

Thus, the inclusion of socio-economic issues in the development of aquaculture must be guided by a preliminary introspective analysis, which questions "why" and "for whom" aquaculture initiatives are promoted to help mitigate impacts with negative consequences on livelihoods including: how are the "rising stars" endorsed in the development of the sector - in other words where there is significant potential for aquaculture growth within the aquaculture industry and how should they be more effectively and proactively included in the planning processes. Similarly, what processes are needed to include issues and concerns that are not currently promoted by active and resourceful stakeholders (Buanes et al., 2004)? More detailed and context-specific socio-economic dimensions of aquaculture operations include many important factors which need to be understood: gender, employment and income, nutrition, food security, health, insurance, credit availability, human rights, legal security, privatization, culture/identity, global trade and inequalities, as well as policies, laws and regulations, macro-economic context, political context, customary rules and systems, stakeholders, knowledge and attitudes, ethics, power, markets, capital and ownership (Hishamunda et al., 2009).

To achieve politically transparent and socially legitimate aquaculture development these socioeconomic factors must be included when setting policy objectives and implementing management mechanisms. Furthermore, this information has to be context-specific to ensure that local conditions, culture and management constraints are all given due consideration in aquaculture development thus ensuring arising actions have considered in advance the impacts likely to accrue from policy recommendations.

However In many cases impacts leading to unsustainability stem from ecological and social feedbacks generated by aquaculture production systems themselves and are reinforced by the gaps existing between "people" and policy. [The term "people" is used in this paper to describe aquaculture stakeholders in a more global sense, referring to socio-economic agents directly or indirectly affected by the structure and dynamics of the aquaculture sector]. These social gaps 
between "people" and policy can be understood as a process in which the stakes of at least one stakeholder are neglected or considered insufficiently in decision-making processes, leading to a kind of exclusion. This exclusion can be internal to the aquaculture sector, or result from the interactions with other users. The former is associated with the exclusion of stakeholders from the decision-making about the aquaculture sector itself. This is related to negligence, or a lack of social equity, in policy making for e.g. coastal communities traditionally working in the aquaculture sector. As an example, in many developing countries governments have prioritised the development of capital-intensive aquaculture devoted to global markets as a basis for national economic development rather than the labour-intensive operations characterizing the extensive and family-run aquaculture companies. This process has been accompanied by public regulations supporting low taxation, facilities for credit, or coastal access, fostering the growth of production. As a result of this development pattern, many poor people from coastal communities with a weak capacity of investment have been marginalized or forced to leave the sector or even have prevented other people getting involved (EJF, 2003; Toufique and Gregory, 2008).

The other type of exclusion relates to other stakeholders concerned. This occurs when policies disregard or do not give fair consideration to the stakes of other agents which are affected by the development of aquaculture systems. These interactions can result from competition for space or pollution emissions. For example, aquaculture development has in many places lead to destruction of coastal wetlands (i.e. mangrove ecosystems) and their associated ecosystem services which supply the needs of many other human users (fisheries, agriculture, recreation, etc.) but which also support other ecosystems and biodiversity equilibria. The social impacts resulting from these externalities have been described extensively in the literature (e.g., EJF, 2003; FAO, 2008b) and include e.g. seepage of salt water in the coastal zone (EJF, 2003; Belton and Little, 2008), the privatization of coastal space, blocking villagers' access to fishing grounds (e.g., Shiva and Karir, 1997), the displacement of commercial and subsistence fisheries due to pollution, etc. (Deb, 1998; FAO, 2008b; Gay Wiber et al., 2012). In spite of significant efforts to resolve these concerns, such as the development of the ecosystem approach to aquaculture by the FAO in 2010, the main issues still remain in many places unsolved (USAID, 2006; Islam, 2008).

\section{Policy Issues in Aquaculture}

At national levels, aquaculture is often seen as a dynamic sector that should be capitalized upon to generate competitiveness and revenues as well as increase well-being and food security. This view is reflected for example in the multiannual national plans for the promotion of sustainable aquaculture proposed by the European Commission (COM, 2013) and can be found as part of national strategic growth plans where food security is included in many countries worldwide. What remains unclear is the extent to which these high-level intentions translate into "peoplecentred aquaculture activities" at local and field levels of investigation. Indeed, while technological innovations promoted in policy initiatives aim to improve and to progress aquaculture development, they often miss the inclusion of "people" in the process (Brugère, 2006; Brugère et al., 2010; Hishamunda et al., 2009). This often results in unintended outcomes that may be detrimental to the very people aquaculture is meant to benefit.

This is because: 
a) even when the people affected by aquaculture are clearly identified, a policy for systematically including them in planning processes is often lacking (see example by Buanes et al. (2004) for salmon farming),

b) due to unclear definitions of system boundaries by policies, important stakeholders affected by aquaculture are often not identified (see example by Joyce and Satterfield (2010) for shellfish aquaculture),

c) the role and responsibilities of individual and institutional stakeholders are rarely clearly defined (see example in Belton (2012) for Tilapia and Pangasius), and

d) regulations pertaining to aquaculture are not streamlined under one umbrella but often range over various policy sectors, such as agriculture and fisheries (see examples in Brugère et al., 2010).

These frequently disconnected planning processes that inadequately consider socio-economic dimensions can lead to aquaculture policies with unclear goals and rules-of-use. In turn it negatively affects the sustainable growth of the sector, the environment and the overall wellbeing of citizens (Barret et al., 2002; Brugère et al., 2010; Veuthey and Gerber, 2012). Aquaculture policies need to be people-oriented and include socio-economic context specific information, whilst being applicable to different aquaculture settings and scales (Figure 1). Institutions that are robust and designed to avoid both resource tragedies and social exclusion must be promoted (Hopkins et al., 2011; Sandberg, 2003) and building processes that support participation of people in decision-making is what this paper recommends. The aquaculture industry as well as governmental bodies, policy-makers and management authorities must acknowledge their dependence on a constant flow of ecosystem services from marine and inland ecosystems, including the influence of different markets from local to international, and also recognize the potential consequences of their activities on both ecological and social systems.

Figure 1 here

\section{Origins of the People-Policy Gap}

Policies operate within an array of federal, regional and international legislations, agreements and treaties. This implies that scale issues are an important cornerstone in the development of aquaculture at the interface of policy, management and governance, yet to-date they have in many cases received little or no attention. In the instance of the former, the EU issued a white paper on governance in 2001 which identified a number of normative principles, namely openness, participation, coherence, efficiency, and proportionality (COM, 2001). It also identified the need to extend the range of policy instruments in the EU to encompass more network-based and market-based modes of governance (COM, 2001). All of these aforementioned principles have to be considered in light of, and are affected by, the scale chosen. In the case of aquaculture, which ranges in empirical reality across many scales, from the local to the global, these are inadequately addressed in current policy schemes. These findings have been reinforced by a recent publication of the HLPE (High Level Panel of Experts on Food Security and Nutrition) in 2014, which stressed the role of social protection and labour rights in aquaculture as well as governance to determine benefits from aquaculture. More often than not, too little attention has been given to the ways different individuals and groups will gain, lose, or be excluded from access to productive supply chain assets of aquaculture (HLPE, 2014). The 
problem of the multi-scale nature of aquaculture is that policies tend to overlook some of the potentially important structural processes of decision-making about development. This leaves questions like 'aquaculture for what and for whom?' equivocal and makes policies with clear objectives difficult to formulate.

Public participation is at the heart of the people-policy gap. Participation in decision-making processes does not always include the voices of many of those impacted directly and indirectly by aquaculture policies. In the case of shrimp farming for instance, Béné (2005) found that the changes in policy orientations which have taken place in recent years allowed key stakeholders to refocus the debate on technical solutions. In its wake it prevented other groups concerned with more intractable social and political issues from engaging successfully in the policy process, thus leaving the long-term sustainability of aquaculture still a contentious issue.

In some countries, effective public hearing mechanisms, zoning and individual licensing procedures are established. However, it is recognized that participation should not be a goal in itself and may need, in some instances, to be traded-off for efficiency (FAO, 2008a). In other places, it is poor governance (e.g. corruption and/or abuse of power by influential stakeholders) that prevents consultation mechanisms from being effectively implemented.

Even in cases where aquaculture is tightly regulated (e.g. salmon farming in Norway), the social impacts of regulations are hard to foresee and tend to remain difficult to determine also after implementation (see Buanes et al., 2004 and Isaksen and Mikkelsen, 2012). The complexity (i.e. being linked from local to global market demands) and context-specificity of the social dimensions of aquaculture make their encompassing by decision-making at higher levels problematic. This pertains specifically to the difficulty in anticipating their emergence and in capturing their effects over different temporal and spatial scales. For instance, timing and sequencing are critical factors in the transition to alternative livelihoods, and for the rest of the economy which is linked to the sector through income and employment multipliers (Béné et al., 2010).

Thus, instead of adopting a static perspective which simply describes the presence and/or absence of particular modes or instruments of governance in aquaculture, future work should explore causal relationships between governance interventions and outcomes 'on the ground'. These outcomes will also depend on other factors related to e.g. the resource base, state of the ecosystem, the regional economy, market forces, social structures, trade patterns, type of aquaculture activity, etc. However, knowing what forms of governance lead to what sorts of outcomes, whilst ensuring that they remain legitimate and publicly accountable, can be the foundation for effective policy making (Jordan, 2008).

Trade is another fundamental element of the people-policy gap. Global trade masks the social and ecological implications of consumption as it distances us from production areas and supporting ecosystems (Deutsch et al., 2011). Aquaculture often takes place in more isolated sites, such as in the case of salmon (Salmo salar) farming in mainly rural settings in Scotland or pangasius (Pangasius bocourti) farming in Vietnam. In case of the former, aquaculture can play a crucial role in providing alternative income options for rural marginalised communities, whereas in case of the latter the global demand drives the intensity of the production with little regard of local ecosystem capacities (Little et al., 2012). As production often occurs in such faraway areas, endconsumers seldom question the conditions under which aquaculture production takes place. Thus, empowering policies are needed that support local people to make trade-off decisions they see best between income and (other) social objectives, or environment for that sake. Recurring protests in production areas, such as in Latin America and Asia against shrimp (Penaeus 
monodon in most cases) aquaculture in the 1990s and, more recently, in Chile in 2012 in connection with salmon farming, illustrate this disconnection between the needs for food production and perceived impacts of aquaculture development on the surrounding environment (Adduci, 2009; Gonzales, 2008; Martinez-Alier, 2001; Veuthey and Gerber, 2012). The urgency to achieve global food security should be another incentive to include social considerations (e.g., acceptability as a valuable source of nutrition) in trade policies, supporting aquaculture production in a broader, integrated and more structured manner.

\section{Outcomes of the People-Policy Gap}

Illustrations of the people-policy gap can be found all over the world. For instance in Norway and Scotland, when modern aquaculture started to develop in the 1970s and 1980s, aquaculture enterprises were started by local entrepreneurs and fishermen with support from their local coastal community. The ownership and benefits of aquaculture remained largely in the community (Peel and Lloyd, 2008; Sandberg, 2003), contributing to livelihoods in peripheral coastal areas, just like the authorities hoped it would (Hersoug, 2013). Over time however, the consolidation of the industry led to the decline of smaller companies (Hersoug and Johnsen, 2012; Isaksen and Mikkelsen, 2012), and crucially, to "critical attention to the appropriateness of the governance arrangements for aquaculture and, specifically, the opportunities for greater civil engagement and democratic decision-making" in its planning and policy context (Peel and Lloyd, 2008). This is exemplified in Norway where some municipalities have voiced their wish to ban aquaculture from their coastal zone, to avoid negative external effects of fish farming and instead use the areas for alternative local job-creation, but have not been allowed to do so by the state authorities (Isaksen and Mikkelsen, 2012). Many Norwegian coastal municipalities are interested in issuing an area- or production-tax on fish farms that directly benefits the municipalities, ensuring that local people reap the benefits of aquaculture production in their community and coastal zone (Hersoug, 2013; Isaksen and Mikkelsen, 2012). Failure to continuously and appropriately address local benefits from aquaculture, an important social dimension of aquaculture, has now led to strong conflicts between aquaculture companies and municipalities in Norway.

This empirical evidence of concentration and more or less job-less growth of the sector in relation to traditional use of proposed aquaculture sites is a main refutation in the ongoing debate about implementing salmon farming in Bantry Bay/Ireland (see e.g. http://bantryblog.wordpress.com/). These issues are not specific to the aquaculture sector alone as many sectors of production are experiencing these challenges. However, some countries governments have reacted to this situation and imposed minimum corporate social responsibility (CSR) of large producers (Huemer, 2010). In the case of Scotland this has led to significant investment in infrastructures like improved roads, schools and other facilities (Georgakopoulos and Thomson, 2008). In Norway however, this has led to a frustration of coastal communities with the current governance regime, as they are excluded from the direct benefits generated by the aquaculture activities and production chain (Huemer, 2010; Sandberg, 2003).

In contrast, in Germany, besides special regulations for traditional mussel (Mytilus edulis) cultivation, which is more seen as fisheries in public perception, aquaculture as a policy issue is still in its infancy (Buck, 2007). In principle, the set of legal instruments provides suitable tools for horizontal, vertical, territorial and time-related coordination of coastal zones, inclusive public participation (Rosenthal and Hilge, 2000). However, some ecosystem-friendly labelled producers 
include social standards into their consumer label criteria which are e.g. related to location, development, and aesthetics of aquaculture sites, as well as public access to aquaculture sites.

Similar negative outcomes of the people-policy gap as described for Norway and Scotland have been documented in Chile with the development of the salmon farming industry (Barret et al., 2002; Buschmann et al., 2009; Gonzales, 2008), as well as in Asia and Central America where the mismatch between an explicit policy orientation towards the industrialization of the shrimp farming sector and local practices, and the inadequacy of the institutional arrangements that should have helped to link the two, led to social conflicts and mangrove destruction (e.g. Beitl, 2012, in the case of Ecuador; Brugère, 2006, in the case of India).

Thus, outcomes of the people-policy gap can vary according to the priorities of a specific government and the contextual country-specific setting. The main message from this section is that proactive action that encourages participation of people in decision-making about aquaculture could help improve acceptance of this sector and improve management that can have more positive impacts on those communities associated with this type of production.

\section{Existing Efforts to Integrate Social and Economic Dimensions in Aquaculture Development}

Although there are a number of frameworks, codes and guiding principles that have attempted to address the socio-economic dimension of aquaculture (see for instance FAO, 2010, 1995; Subasinghe et al., 2010), they are falling short of identifying the social framing conditions at any depth that can help policy-makers include guidelines so selected management measures can take account of future impacts to peoples livelihoods. Thus, people-specific effects of aquaculture production are not fully considered and we highlight herein that having a process which helps frames aquaculture production in a way that is easily understandable by policy-makers is one way to address the current gap in knowledge. To illustrate this finding, the ecosystem approach to aquaculture (EAA) for instance aims to promote a harmonious and coherent development of aquaculture (FAO, 2010). Although the participation of stakeholders is at its core, experiences have shown that, despite these intentions, the people most affected by aquaculture operations are often not involved in decision-making about aquaculture development policies (Gonzales, 2008). This lack of participation has been addressed by recent FAO-led initiatives such as the 2010 Phuket declaration (Subasinghe et al., 2010). In the declaration the need was stressed to assess the role of aquaculture for regional and global economies, poverty alleviation and food security. Likewise, the FAO Code of Conduct for Responsible Fisheries (FAO, 1995) strives to integrate socio-economic considerations, e.g. by stating in Article 9 that livelihoods of local communities and access to fishing grounds must not be negatively affected by aquaculture. However, these declarations remain elusive on how to deal with these socio-economic issues in practice.

Livelihood-based frameworks were developed to broaden the understanding of poverty and to guide poverty alleviation interventions. They focused attention on the multiplicity of social, economic, environmental and institutional factors that needed to be considered to promote sustainable livelihoods. Despite some success in fisheries (Allison and Horemans, 2006), their application to aquaculture has been limited and their relevance for macro-level policy-making has been ambiguous (Scoones, 2009).

The divergent views expressed during the open consultation in 2013 on the study of the High Level Panel of Experts (HLPE) of the UN Committee on World Food Security (CFS) regarding the role of sustainable fisheries and aquaculture for food security and nutrition in early 2013 (http://www.fao.org/fsnforum/cfs-hlpe/fisheries-and-aquaculture) also highlights the breadth and 
controversial nature of the 'socio-economic dimensions' that need to be encompassed and addressed in policy making (FAO, 2012b). This diversity of opinion can lead to delays in decision-making and confusion over how best to integrate socio-economic data with ecological information. Thus frameworks can serve to outline what information is needed, why, who needs to be consulted and participate in the decision-making process.

Common to all of these efforts is that despite increased awareness of the need for integration among disciplines, sectors, and resource users, many researchers, experts, NGOs and policy makers continue to address issues related to the sustainability of aquaculture development from disciplinary perspectives in parallel. Co-ordination of interdisciplinary approaches and frameworks would support a more streamlined analysis of aquaculture development, and knowhow to achieve decision-making that actively involves participation of people. This is urgently needed if aquaculture is to realise its full potential in contributing to reducing global food insecurity among other policy outcomes.

\section{A framework to account for social, economic and ecological issues in aquaculture management and governance}

To bridge the people-policy gap, a central challenge identified from our research is how to comprehensively account for varied socio-cultural, economic, governance and ecological settings encountered in aquaculture development sites. A wide range of data and tools have been obtained and developed to achieve sustainability objectives in aquaculture. Less progress has been made towards utilizing this to influence and implement practical management decisions. This is largely due to the fact that approaches to capture the complexity of the linkages between aquaculture operations and their economic, social, institutional and natural environment are rare. An analytical framework for aquaculture is needed to consistently account for contextual socioeconomic issues in management, policy, and governance. To address these needs and to bridge the people-policy gap we have identified, we propose a framework for an integrated assessment of the various dimensions of aquaculture (Figure 2). This is in line with the recommendations made by the FAO expert consultation on the assessment of socio-economic impacts of aquaculture held in 2008 (FAO, 2008c).

Our point of entry is the assessment of the framing conditions for aquaculture. These framing conditions constitute the "rules of the game" for the specific ecosystem, e.g., freshwater or marine, which explicitly includes theories building on new institutional economics (e.g. North, 1991). They are driving those activities that influence how aquaculture activities are managed and include: policies, laws and standards; macro-economic context; political context; customary rules and systems; stakeholders; knowledge and attitudes; technology; power; markets; and ownership. Ownership includes all aspects of property rights, i.e. the right to use the good, the right to earn income from the good, the right to transfer the good, the right to transform the good and the right to enforce property rights.

Access, particularly as it relates to knowledge, technology, and markets, is also an important element of the framing conditions. In these contexts, access is also related to power and ownership in the aquaculture scenario. Many socio-economic variables related to aquaculture can be "broken down" into a complex series of "second-tier variables" (e.g. Ostrom et al., 2007) which are interrelated across different spatial and temporal scales. 
For example, employment is more than just the number of people employed. It can be directly or indirectly related to, among others, improvements in quality of life, immigration, demographics, and consumption of natural resources (for a broad discussion of the impact of jobs on society compare World Bank 2012). Although we do not specifically focus on these here, it is important to acknowledge that environmental preconditions (space, habitats, state, and protection measures for maintaining ecosystems, to name a few) will also influence aquaculture development. Hence, within our proposed analytical framework, the assessment of framing conditions highlights the characteristics of the system that influence, or drive, aquaculture operations whilst taking into account the capacity to implement those actions. It thus recognizes and reflects the distinct role aquaculture holds in the food production sector, namely that it, in a multi-level manner, requires, as well as affects, people with positive and negative outcomes in each of the aquaculture process steps involved.

The framework presented in Fig. 2 has four main steps. Being cyclical and iterative, it supports an adaptive management approach which encapsulates short-term or long-term effects on the framing conditions and/or the variables identified in the assessment. The framework is rooted in the notion that any aquaculture production is embedded in a social-ecological system context.

Figure $2 \mathrm{a}$ and $\mathrm{b}$ here

A participative approach where stakeholders are given the option to be involved in the decisionmaking process is integral to all stages of this aquaculture governance framework. Although it is clear that scientists will play an active role in the scoping and assessment stages of the framework, while decision-makers are mostly involved in the final stage, iterative communication between all is critical throughout the process to ensure the effective integration of science with "people" in the decision-making context is continually renewed.

\section{Step 1: Assessment and design of framing conditions, stakes and issues}

In this first step the assessment and definition of the framing conditions necessary is gathered on different dimensions for correctly defining the main issues relevant for a particular aquaculture context. This includes also the policy objectives that society can potentially consider, and management options to be implemented for reaching specific objectives. The first step should also include a critical assessment of the underlying assumptions of aquaculture, such as stated aims of poverty alleviation and alternative livelihood development. Misplaced assumptions about the socio-economic outcomes of e.g. mariculture implementation or the role and interests of the state may lead to unintended outcomes and deepen, or serve to create, dependencies and power inequalities (e.g., Sievanen et al., 2005; Davis and Ruddle, 2013).

Stakeholders participate to build the main issue and the policy options. For instance, using "direct employment" as a second-tier variable, the "willingness and capacity to engage in aquaculture" can be analysed under different scenarios. This directly shapes the input variable, i.e. "number of people employed" in Step 2. Thus, building on a systematic identification of framing conditions of aquaculture in the scoping stage, key stakeholders identified will play a critical role in shaping, informing and implementing the process. By this approach an appropriate identification of data required for a given aquaculture setting is possible.

\section{Step 2: Analysis of core processes into the aquaculture sector sub-system}


The second step deals with the analysis of the core processes which enables comprehension of how the particular aquaculture system functions. This step requires multidisciplinary and collective expertise to correctly interpret the economic, social and ecological properties, relationships, and feedbacks related to the issues in question. Actions and decisions can be linked with the business level. Here the input of resources is transformed into outputs of the aquaculture unit. Inputs and outputs can have direct and indirect impacts on different spatial scales (local, regional and global) as well as on the other different dimensions of the system. These social, economic and ecological dimensions can be taken into account with respect to different stakeholders as well.

Drawing on the example of "direct employment", several output variables can be generated. Mostly they pertain to capital economy, however non-cash economy oriented forms of aquaculture for subsistence and barter may hold important local functions. Thus, within the social domain, output variables entail e.g. "proportion of local population employed" (having a localscale dimension), "change in crime rate" (local-scale effect), and "demographic dimension of employment" (ranging from local to national level), or more non-cash variables such as 'food/nutritional security increased', 'more constant protein supply achieved' (local to regional scale effects). In the economic domain, the output variable of "direct employment" would encompass e.g. "change in purchasing power" (local to regional scale) or "salary of worker" (local scale). Within the ecological dimension, one output variable under this topic would relate to "changes in demand for wild resources" (local- to global-scale dimension).

As shown by the example, scale hereby is not viewed as a dimension that can be pre-determined, but rather as a dynamic characteristic which will be defined by the aquaculture scenario and key variables identified in the assessment stage. Stakeholders participate in the calibration appraisal of the framework. This integration allows consideration of new points, issues and shared visions, since participants better understand how they interact (via a model that aids visualization of the many different aspects) with other stakeholders (see example in Cugier et al., 2010).

\section{Step 3: Appraisal and integrated assessment}

In the third step, the outcomes of the aquaculture core activities are assessed, supported by expertise, e.g., analytical retrospective, modelling and sustainability indicators. Especially for the latter, stakeholders can contribute to build indicators according to stakeholder priorities, which reflect their situated knowledge and localized central issues of the respective aquaculture system. Such indicators can vary much across geographic, cultural and social dimensions as well as scales from global to local.

Differences between countries and heterogeneity within them constrain the adaptation and wide use of national-level indicators. For this reason, an emphasis on the development of village- or local-level indicators has occurred during recent years (e.g., Fontalvo-Herazo et al., 2007). This consists of the selection of indicators which best match the context, and is a central item in this step of the framework.

\section{Step 4: Implementation}

Lastly, the fourth step involves the implementation of management interventions which can modify the framing conditions via feedbacks. For example, this may involve in the context of a cash-economy orientation of production, the implementation of new rules or the conditioning of stakeholders' behaviour with appropriate economic or social mechanisms, like incentives and sanctions. These feedback effects can generate contextual and suitable dynamics within the system on different scale levels. Hereby stakeholders can participate in deciding which 
management processes are most appropriate for the specific case. Feedbacks among ecosystem services and human well-being become stronger and more complex (Carpenter et al., 2009). Therefore in the implementation stage it is crucial to consider the full ensemble of processes and feedbacks, for a range of biophysical and social systems, to better understand and manage the dynamics of the relationship between humans and the marine ecosystems on which they rely. Although these policies and practices are not widely adopted at present, some offer the prospect of a better path and optimization through the ongoing transitions.

However, transaction costs have to be taken into consideration for the analysis of the system but in particular also for proposed changes.

\section{Bridging the People-Policy Gap: a discussion}

The analytical approach adopted for the framework was developed based on examination of peerreviewed literature and expert opinion by the authors. The latter incorporated experience in social, economic, ecological, technological, institutional, management and policy-making relevant to aquaculture development at multi-levels of governance (individual, local, national, regional and international) from different parts of the world including Europe, Western Indian Ocean and South East Asia. Much of this experience is unpublished and this framework illustrates the outcomes through the first opportunity for experts to share and integrate their knowledge in a way that can be helpful to policy-makers. Inevitably, our theoretical analysis has led us to examine institutional and political processes primarily at the central level of our concerted efforts. This is of course not to suggest that a lack of economic and ecological data within this analysis can be omitted. However, our approach suggests that national level political and institutional processes strongly structure decision making at that level and are necessary to understand if the goal is to explain the social outcomes of aquaculture production.

Therefore, the above framework aims to promote the understanding that aquaculture operations are social-ecological systems acting under specific economic conditions. That said, we are aware that in reality, the interplay between participation, policy and politics more often than not are dynamic and thus difficult to fully capture at any one time The reality is that different groups act to promote their interests, regardless of any type of participatory processes - different government department, local elites, industry members, NGOs, not to mention affected people in this orchestra. Indeed, these systems are complex and adaptive, with social and biophysical agents interacting at multiple temporal and spatial scales (Janssen and Ostrom, 2006). This has stimulated researchers of many disciplines to look for new ways of understanding and responding to changes and drivers in both the systems and their interactions (Zurek and Henrichs, 2007). Both the social origins of unsustainable ecosystem management and the social repercussions of environmental management are central to these approaches.

This view has been reflected in the ecosystem approach to aquaculture development, which promotes the integration of the social, economic and ecologic dimensions as the bases of sustainability (Costa-Pierce, 2010). As in integrated management planning, this integration is supported by dynamic iterative processes occurring in various phases from the preliminary stages through to policy implementation (Henocque and Denis, 2001; Salm et al., 2000). The proposed aquaculture governance framework mirrors this integration and dynamics. The framework is designed to make the best use of existing data, expert opinion and scientific tools for decisionmaking. It is applicable to multiple spatial scales, ranging from individual farms to addressing global impacts. It supports implementation of an integrated approach in practice thus could be generalizable for different aquaculture production types in various ecosystems. 
The framework thus is a first step towards a more holistic view of the aquaculture industry targeting policy-makers initially as a guideline to help them identify what information is needed when developing policy that can support practical and implementable management options. So far, the bias towards applying principles of scientifically-based aquaculture studies might justify certain management practices determining how the marine resources were used. Yet doing so in the absence of the socio-economic context can lead to negative consequences on people directly and indirectly impacted by aquaculture production. However, difficulties arise in justifying procedures concerning who profits from marine resource exploitation. The latter is a largely social and political matter, not a direct ecological concern. However if this is done with poor governance, for example, a lack of transparency and accountability then resultant distrust among people can impact the success of an aquaculture value chain. Yet, the rules of aquaculture that evolved over the past decades, based on notions of 'managing' marine resources for aquaculture practices, were almost all oriented toward determining who could gain access to a certain marine area and how much they would be taxed (see example of salmon tax practices in Norway, Isaksen and Mikkelsen 2012).

More recently, greater stress has been placed on local participation, and design of elaborate plans for managing aquaculture. These plans simultaneously spell out the use rights of local populations and new labour obligations if they exercise these rights. We found that, similar to the observations on forestry management by Ribot et al., 2006, the principles behind management plans cannot be supported by ecological science alone (Davis and Ruddle, 2012). Indeed, Ribot (2001) showed that one might expect that 'participatory' forestry programs would take greater account of problems experienced by local populations. However, he showed in the case of forestry that user 'rights' of rural populations are privileges that can be taken away at any time, if commercial interests choose to expand their operations. Thus, this is an example of poor governance and a lack of participation by people in the decision-making process.

Thus, a central aspect of equity, enfranchisement and citizenship is access to commercial opportunities, not just subsistence privileges (Ribot, 2001). Current efforts to include people in the aquaculture production chain must therefore also dismantle the separation between commercial and subsistence motives. Otherwise they run the risk of strengthening the rich-poor, or rural-urban- and central- marginal, intensive-extensive divides that participatory approaches have aimed to address. An important component of this is to understand the role aquaculture plays in subsistence versus income generation which will influence peoples' behavior towards aquaculture development and which can best be fully understood through the undertaking of comprehensive socio-economic baseline field studies.

Hence, socially-sound aquaculture development relies on the understanding of two fundamental aspects: (A) the conditions that aquaculture operates under and (B) the mechanisms and channels by which aquaculture affects the social fabric. The latter term encapsulates the social contextspecific setting in a particular ecosystem with its respective people and their attributes, e.g. knowledge holders, right holders, access to power holders, gender and institutions, among others. These framing conditions influence how aquaculture is likely to develop and how certain impacts are likely to occur. Amongst the framing conditions, we note that the systematic description of the social and cultural elements relevant to sustainable aquaculture development is still in its infancy.

The lack of functioning systems for description of various social dimensions for sustainable management has surfaced prominently in the current debate on new forms of marine spatial 
planning. Although international maritime policies (e.g. Canadian Oceans Act, the EU Water Framework and Marine Strategy Directives, to name but a few) include components like: 1) a knowledge-based approach for decision making, and 2) an ecosystem-based approach for integrative management, the approaches are mostly environmentally-orientated, and poorly recognize the social functions of nature and its natural resources. Making nature a commodity remains a moral problem even in a market-driven economy (McCay, 1998). Questions on who decides what and when as well as ownership issues remain unanswered yet have important implications for natural resource user behaviour. For instance for the latter, the large-scale aquaculture developments in Norway have triggered a debate on who decides on the future of the sea and what criteria are used to take such decisions. How to prioritise different stakeholders' views and concerns in aquaculture policy development is unclear. The framework presented herein offers a solution and way forward to governments around the world on what information is required and linkages that need to be considered as part of decision-making.

Unresolved issues of which stakeholders are involved in the consent procedure, their role and their relative influence is also crucial to resolve for bridging the people-policy gap. These findings are underlined by the experiences made with shellfish cultivation in several places within the regional scope of the Northeast Atlantic of the International Council for the Exploration of the Sea (ICES) member countries (see also recent ICES reports of the WGMASC, WGAQUA and SGSA). Social dimensions in aquaculture operations can be difficult to capture, e.g. emotional ownership of the sea/coastal area by local residents/stakeholders and the social and cultural values that drive this ownership. However, the identification and recognition of stakeholders and their supporting values are not included in the decision-making process (ICES, 2011). Furthermore, keeping all stakeholders in agreement - leading to the "contracting costs" (the cost, not necessarily in money, of getting a group of people to agree on an issue) that make it so difficult to enact major institutional change that affects natural resources and their use (McCay, 1998).

The application of the presented analytical framework is a way for policy-makers and stakeholders to visualize the complex sets of information, and thus support a more advanced understanding of the role people play in the overall design, development, operation and outcome of aquaculture operations. The identification and monitoring of feedbacks between planning and policy procedures and social outcomes throughout the aquaculture development process is a timely endeavour and high on political agendas worldwide given the interest in aquaculture for contributing to achieve food security, income and livelihoods.

\section{Recommendations for bridging the people-policy gap}

The people-policy gap can lead to a disconnect between flows of benefits and intended beneficiaries, uneven distribution and generation of ecosystem services at multiple scales, and detrimental effects on health and food security, all of which can have negative repercussions on human communities and ecosystems. These, in turn, affect the overall sustainability of aquaculture development. To avoid this, particular attention is needed with respect to:

- Equal consideration of ecological, social and economic issues in aquaculture policymaking that supports management choices that are practical and implementable. 
- Pre-emptive identification of likely social impacts of aquaculture operations (using appropriate system boundaries) before any attempts are made to introduce aquaculture so that proactive steps can be taken to avoid negative consequences to the environment, people, their livelihoods and associated businesses.

- Integration of people- and context-specific social framing conditions into planning and policy review so that resultant management measures are more likely to add value to a particular socio-economic and ecosystem.

- Addressing the social disconnect between global consumption and production via stakeholder participation and continuous transdisciplinary dialogues.

- Encouragement of creative combinations of theories and methods widely applicable to assess and interpret the social dimensions of aquaculture in multiple contexts.

\section{Conclusions}

Major drawbacks to the further sustainable expansion of the aquaculture sector that need to be overcome include disciplinary and sectoral barriers which are complex (conceptually as well as logistically), costly, and time-consuming. However, the continued pursuit of individual lines of investigation is likely to fail to bring about the benefits associated with the integrated approach developed herein and that the framework helps to visualise. Many aquaculture developments can be outright social failures due to a lack of effective stakeholder participation and/or understanding of how people's activities influence ecosystems which if understood could for example address negative concerns like poaching. Equally noteworthy is aquaculture can have negative impacts on economic and environmental characteristics of an ecosystem thus taking account of these different dimensions and linking to others such as political and governance factors can be advantageous in development of context-appropriate management.

The application of the analytical framework presented will enable a more informed understanding and assessment of the multiple dimensions related to aquaculture development, implementation and operation. Steps to increase understanding of this complexity will enable bridging of the people-policy gap and lay the foundations for sustainable aquaculture development to continue and to fulfil its important role worldwide in decades to come. This novel framework could act as the catalyst required to start the 'policy revolution' through including people in decision-making about aquaculture development and thus closing the current people-policy gap and enabling aquaculture to help reduce the global societal issues of food insecurity.

\section{Acknowledgements}

This paper is based on extensive discussions at the regular meetings of the International Council for the Exploration of the Sea (ICES) Study Group on Socio-Economic Dimensions of Aquaculture over the last three years. We thank Michael Vakily and Willy Versluys for granting the permission to use their photographs and the helpful comments of an anonymous reviewer on an earlier version of this paper. 


\section{References}

Adduci, M., 2009. Neoliberal Wave Rocks Chilika Lake, India: Conflict over Intensive Aquaculture from a Class Perspective. J. Agri. Change. 6, 484-511.

Ahmed, M., Lorica, M., 2002. Improving developing country food security through aquaculture development - Lessons from Asia. Food Policy 27, 125-141.

Allison, E.H., Horemans, B., 2006. Putting the principles of the Sustainable Livelihoods Approach into fisheries development policy and practice. Mar. Policy. 30, 757-766.

Badjeck, M.-C., Perry, A., Renn, S., Brown, D. \& Poulain, F. 2013. The vulnerability of fishingdependent economies to disasters. FAO Fisheries and Aquaculture Circular No. 1081. Rome, FAO. pp.19.

Barret, G., Caniggia, M., Read, L., 2002. "There are More Vets than Doctors in Chile": Social and Community Impact of the Globalization of Aquaculture in Chile. World Development. 30(11), 1951-1965.

Barton, J.R., Fløysand, A., 2010. The political ecology of Chilean salmon aquaculture, 19822010: A trajectory from economic development to global sustainability. Global Environmental Change. 20, 739-752.

Beitl, C.M., 2012. Shifting policies, access, and the tragedy of enclosures in Ecuadorian mangrove fisheries: towards a political ecology of the commons. University of Georgia, USA.

Belton, B., Bush, S.R., 2014. Beyond net deficits: new priorities for an aquacultural geography. The Geographical Journal. 180(1), 3-14.

Belton, B., Haque, M.M., Little, D.C., Sinh, L.X., 2011. Certifying catfish in Vietnam and Bangladesh: Who will make the grade and will it matter? Food Policy 36, 289-299.

Belton, B., Little, D.C., 2011. Immanent and Interventionist Inland Asian Aquaculture Development and its Outcomes. Dev. Policy Rev. 29, 459-484.

Belton, B., Little, D.C., 2008. The Development of Aquaculture in Central Thailand: Domestic Demand versus Export-Led Production. Journal of Agrarian Change. 8 (1), 123-143.

Béné, C., Hersoug, B., Allison, E.H., 2010. Not by Rent Alone: Analysing the Pro-Poor Functions of Small-Scale Fisheries in Developing Countries. Development Policy Review. 28(3), 325-358.

Béné, C., 2005. The Good, the Bad and the Ugly: Discourse, Policy Controversies and the Role of Science in the Politics of Shrimp Farming Development. Dev. Policy Rev. 23, 585-614. 
Beveridge, M.C.M., Thilsted, S.H., Phillips, M., Metian, M., Troell, M., Hall, S. J., 2013. Meeting the food and nutrition needs of the poor: the role of fish and the opportunities and challenges emerging from the rise of aquaculture. Journal of Fish Biology, 83(4), 1067-1084.

Beveridge, M.C.M., Little, D.C., 2002. The History of Aquaculture in Traditional Societies, in: Costa-Pierce, B.A. (Ed.), Ecological Aquaculture. Blackwell Science Ltd, pp. 3-29.

Bradshaw, G.A., Borchers, J.G., 2000. Uncertainty as information: narrowing the science-policy gap. Conservation Ecology. 4(1), 7.

Brugère, C., 2006. Can Integrated Coastal Management Solve Agriculture-Fisheries-Aquaculture Conflicts at the Land-Water Interface? A Perspective from New Institutional Economics, in: Huong, C.T., Tuong, T.P., Gowing, J.W., Hardy, B. (Eds.), Environment and Livelihoods in Coastal Tropical Zones: Managing Agriculture-Fishery-Aquaculture Conflicts. CABI, Oxon, pp. 258-273.

Brugère, C., Ridler, N., Haylor, G., Macfadyen, G., Hishamunda, N., 2010. Aquaculture planning: policy formulation and implementation for sustainable development. FAO Fisheries and Aquaculture Tech. Paper No. 542, Rome.

Buanes, A., Jentoft, S., Karlsen, G.R., Maurstad, A., Søreng, S., 2004. In whose interest? An exploratory analysis of stakeholders in Norwegian coastal zone planning. Ocean \& Coastal Management. 47(5-6), 207-223.

Buchholz, C., Krause, G., Buck, B.H., 2012. Seaweed and Man, in: Wiencke, C., Bischof, K. (Eds.), Seaweed Biology: Novel Insights into Ecophysiology, Ecology and Utilization. Springer, Heidelberg, Berlin, pp. 471-493, p 509.

Buck, B.H., 2007. Experimental trials on the feasibility of offshore seed production of the mussel Mytilus edulis in the German Bight: Installation, technical requirements and environmental conditions. Helgoland Marine Research. 61, 87-101.

Bunting, S.W., 2004. Wastewater aquaculture: perpetuating vulnerability or opportunity to enhance poor livelihoods? Aquatic Resources, Culture and Development. 1, 51-75.

Buschmann, A.H., Cabello, F., Young, K., Carvajal, J., Varela, D.A., Henríquez, L., 2009. Salmon aquaculture and coastal ecosystem health in Chile: Analysis of regulations, environmental impacts and bioremediation systems. Ocean \& Coastal Management. 52, 243-249.

Carpenter, S.R., Mooney, H.A., Agard, J., Capistrano, D., DeFries, R.S., Díaz, S., Dietz, T., Duraiappah, A.K., Oteng-Yeboah, A., Pereira, H.M., Perrings, C., Reid, W.V., Sarukhan, J., Scholes, R.J., Whyte, A., 2009. Science for managing ecosystem services: Beyond the Millennium Ecosystem Assessment. PNAS. 106(5), 1305-1312.

COM, 2013. 229 final: Strategic Guidelines for the sustainable development of EU aquaculture. COM, Brussels.

COM, 2001. 428 final: European Governance: a white paper. COM, Brussels. 
Costa-Pierce, B., 2010. Sustainable ecological aquaculture systems: The need for a new social contract for aquaculture development. Mar. Tech. and Soc. J. 44, 1-25.

Cressey, D., 2009. Aquaculture: Future fish. Nature. 458, 398-400.

Cugier, P., Struski, C., Grangere, K., Blanchard, M., Frangoudès, K., Robin, T., Pérez, J., Mongruel, R., Mazurié, J., LeMao, P., Fontenelle, G., 2010. Impacts of environmental factors and shellfish practices on the Mont-St-Michel Bay ecosystem (France). A modelling study involving scientists, stakeholders and users of the bay, in: International Environmental Modelling and Software Society (iEMSs), International Congress on Environmental Modelling and Software, Ottawa, Canada.

Davis, A., Ruddle, K., 2012. Massaging the Misery: Recent Approaches to Fisheries Governance and the Betrayal of Small-Scale Fisheries. Hum. Organ. 71, 244-254.

Deb, A.K., 1998. Fake blue revolution, environmental and socio-economic impacts of shrimp culture in the coastal areas of Bangladesh Ocean and Coastal Management, 4, 63-88.

Deutsch, L., Troell, M., Limburg, K., Huitric, M., 2011. Global Trade of Fisheries Products: implications for marine ecosystems and their services, in: Köllner, T. (Ed.), Ecosystem Services and Global Trade of Natural Resources: Ecology, Economics and Policies. Routledge, London, p. 304.

Dürrenberger, G., Kastenholz, H., Behringer, J., 1999. Integrated assessment focus groups: Bridging the gap between science and policy? Science and Public Policy. 26(5), 341-349.

EJF (Environmental Justice Foundation), 2003. Risky Business: Vietnamese Shrimp Aquaculture-Impacts and Improvements. Environmental Justice Foundation, London, UK.

FAO, 2014. The state of world fisheries and aquaculture, 2014. Food \& Agriculture Organization of the United Nations. Rome, Italy.

FAO, 2012a. The State of World Fisheries and Aquaculture 2012. FAO, Rome.

FAO, 2012b. Committee on World Food Security. FAO, Rome.

FAO, 2010. Aquaculture development: 4. Ecosystem approach to aquaculture. FAO Tech. Guidelines for Responsible Fisheries No. 5, Suppl. 4, Rome.

FAO, 2008a. Report of the Expert Consultation on Improving Planning and Policy Development in Aquaculture. FAO Fisheries Rep. No. 858, Rome.

FAO, 2008b. Expert Consultation on the Assessment of Socio-economic Impacts of Aquaculture. Report 861, Rome p. 53.

FAO, 2008c. Report of the Expert Consultation on the Assessment of socio-economic Impacts of Aquaculture. Fisheries Report No. 861, Ankara. 
FAO, 1995. Code of Conduct for Responsible Fisheries. FAO, Rome.

Fischhoff, B., 2012. Communicating Uncertainty Fulfilling the Duty to Inform. Issus in Science and Technology. 28(4), 63-70.

Fontalvo-Herazo, M.L., Glaser, M., Lobato-Ribeiro, A., 2007. A method for the participatory design of an indicator system as a tool for local coastal management. Ocean \& Coastal Management. 50(10), 779-795.

Fröcklin, S., de la Torre-Castro, M., Lindström, L., Jiddawi, N.S., Msuya, F.E. 2012. Seaweed mariculture as a development project in Zanzibar, East Africa: A price too high to pay? Aquacult. 356-357, 30-39.

Gay Wiber, M., Wilson, L. and Young, S., 2012. Impact of Aquaculture on Commercial Fisheries: Fishermen's Local Ecological Knowledge. Human Ecology 40(1), 29-40.

Georgakopoulos, G., Thomson, I., 2008. Risk, Risk Conflicts, Sub-politics and Social and Environmental Accounting and Accountability in Scottish Salmon Farming. Amsterdam Business School Research Institute, Netherlands, p. 41.

Gonzales, E., 2008. Chile's National Aquaculture Policy: missing elements for the sustainable development of aquaculture. Int. J. Environ. and Pollution. 33, 457-468.

Graffy, E.A., 2008. Meeting the Challenges of Policy-Relevant Science: Bridging Theory and Practice. Public Administration Review. 68(6), 1087-1100.

Hall, S.J., Delaporte, A., Phillips, M.J., Beveridge, M., O’Keefe, M., 2011. Blue Frontiers: Managing the environmental costs of aquaculture. The World Fish Center. Penang, Malaysia.

Henocque, Y., Denis, J., 2001. A methodological guide: steps and tools towards integrated coastal area management. IOC Manuals and Guides. 2(42), 65.

Hersoug, B., 2013. The Battle for Space - the Position of Norwegian Aquaculture in Integrated Coastal Zone Planning, in: Moksness, E., Dahl, E., Støttrup, J. (Eds.), Global Challenges in Integrated Coastal Zone Management. Wiley-Blackwell, Oxford, pp. 159-168.

Hersoug, B., Johnsen, J.P., 2012. Hvem skal bruke kystsonen. Universitetsforlaget, Oslo, Norway, pp. 13-18.

Hishamunda, N., Cai, J., Leung, PS., 2009. Commercial aquaculture and economic growth, poverty alleviation and food security. FAO Fisheries and Aquaculture Tech. Paper, no. 512, Rome.

HLPE, 2014. Sustainable fisheries and aquaculture for food security and nutrition. A report by the High Level Panel of Experts on Food Security and Nutrition of the Committee on World Food Security. Rome. pp.118. 
Hopkins, T.S., Bailly, D., Støttrup, J.G., 2011. A systems approach framework for coastal zones. Ecology and Society. 16(4), 25.

Huemer, L., 2010. Corporate Social Responsibility and Multinational Corporation Identity: Norwegian Strategies in the Chilean Aquaculture Industry. Journal of Business Ethics. 91, 265277.

ICES, 2011. Report of the Study Group on Social Dimensions of Aquaculture (SGSA). ICES, Bremen.

Isaksen, J., Mikkelsen, E., 2012. Økonomer i kystsonen: Kan kunnskap om verdiskaping gi bedre arealforvaltning?, in: Hersoug, B., Johnsen, J.P. (Eds.), Kampen om plass på kysten. Interesser og utviklingstrekk i kystsoneplanleggingen. Universitetsforlaget, Oslo, pp. 159-178.

Islam, M.S. 2008. From pond to plate: towards a twin-driven commodity chain in Bangladesh shrimp aquaculture. Food Policy. 33 (2008), pp. 209-223.

Janssen, M.A., Ostrom, E., 2006. Governing Social-Ecological Systems. Handbook of Computational Economics. 2, 1465-1509.

Jentoft, S., Chuenpagdee, R., 2013. Concerns and Problems in Fisheries and Aquaculture Exploring Governability, in: Bavinck, M., Chuenpagdee, R., Jentoft, S., Kooiman, J. (Eds.), Governability of Fisheries and Aquaculture. Springer, Netherlands, pp. 33-44.

Jones, S.A., Fischhoff, B., Lach, D., 1999. Evaluating the science-policy interface for climate change research. Climate change. 43, 581-599.

Jordan, A., 2008. The governance of sustainable development: taking stock and looking forwards. Environment and Planning C: Government and Policy. 26, 17-33.

Joyce, A.L., Satterfield, T.A., 2010. Shellfish aquaculture and First Nations`sovereignty: The quest for sustainable development in contested sea space. Natural Resources Forum. 34, 106-123.

Kaiser, M., Stead, S.M., 2002. Uncertainties \& values European aquaculture: communication, management \& policy issues in times of changing public perceptions. Aquaculture International. $10,469-490$.

Lan, 2013. Social and ecological challenges of market-oriented shrimp farming in Vietnam. SpringerPlus 2013 2:675.

Little, D.C., Bush, S.R., Belton, B., Phuong, N.T., Young, J.A., Murray, F.J., 2012. Whitefish wars: Pangasius, politics and consumer confusion in Europe. Mar. Pol. 36, 738-745.

Lubchenco, J., 1998. Entering the Century of the Environment: A New Social Contract for Science. Science. 279(5350), 491-497.

McCay, B., 1998. Oyster Wars and the Public Trust: Property, Law, and Ecology in New Jersey History. Univ. Arizona Press, Tucson. 
MacNeil, M.A., Graham, N.A.J., Cinner, J.E., Dulvy, N.K., Loring, P.A., Jennings, S., Polunin, N.V.C., Fisk, A.T., McClanahan, T.R., 2010. Transitional states in marine fisheries: adapting to predicted global change. Phil. Trans. R. Soc. B. 365, 3753-3763.

Martinez-Alier, J., 2001. Ecological conflicts and valuation: mangroves versus shrimps in the late 1990s. Environment and Planning C: Government and Policy. 19(5), 713-728.

Nagarajan, R., Thiyageasan, K., 2006. The effect of coastal shrimp farming on birds in Indian Mangrove forests and tidal flats. Acta Zoologica Sinica. 52, 541-548.

North, D.W., 1991. Do We Know Enough to Take a Risk-Based Approach. EPA J. 17, 31.

North, D.C., 1990. Institutions, Institutional Change and Economic Performance. Cambridge University Press, Cambridge, UK.

Ostrom, E., Janssen, M.A., Anderies, J.M., 2007. Going beyond panaceas. PNAS. 104(39), 15176-15178.

Ostrom, E., 2005. Understanding Institutional Diversity. Princeton University Press, Princeton, NJ, USA.

Peel, D., Lloyd, M.G., 2008. Governance and planning policy in the marine environment: regulating aquaculture in Scotland. The Geographical Journal. 174(4), 361-373.

Ribot, J.C. 2001. Science, use rights and exclusion: a history of forestry in Francophone West Africa. London, International Institute for Environment and Development.

Ribot, J.C., Agrawal, A., Larson, A.N., 2006. Recentralizing While Decentralizing: How National Governments Reappropriate Forest Resources. World Development. 34(11), 1864-1886.

Rosenthal, H., Hilge, V., 2000. Aquaculture production and environmental regulations in Germany. Journal of Applied Ichthyology. 16(4-5), 163-166.

Ruddle, K., Davis, A., 2013. Human rights and neo-liberalism in small-scale fisheries: Conjoined priorities and processes. Mar. Pol. 39, 87-93.

Salm, R.V., Clark, J., Siirila, E., 2000. Marine and Coastal Protected Areas: A guide for planners and managers. IUCN, Washington DC.

Sandberg, A., 2003. Commons for Whom? New Coastal Commons on North-Norwegian Coasts, in: Sandberg, A., Berge, E., Carlsson, L. (Eds.), Landscape, Law \& Justice: Proceedings from a workshop on old and new commons. Dept. of Sociology and Political Science, Norwegian University of Science and Technology, Trondheim, Norway, pp. 135-140.

SCAR-Fish, 2013. Science in support of the European fisheries and aquaculture policy. European Com., Brussels, pp 49. 
Schlüter, A., Wise, S., Schwerdtner Mánez, K., de Morais, G.W., Glaser, M., 2013. Institutional Change, Sustainability and the Sea. Sustainability. 5, 5373-5390.

Scoones, I., 2009. Livelihoods perspectives and rural development. J. Peasant Studies. 36, 171196.

Shiva, V., Karir, G. 1997. Towards sustainable aquaculture. Research Foundation for Science, New Dehli, India, pp. 133.

Sievanen, L., Crawford, B., Pollnac, R.B., Lowe, C., 2005. Weeding through assumptions of livelihood approaches in ICM: Seaweed farming in the Philippines and Indonesia. Ocean \& Coastal Management. 48, 297-313.

Sinh, X., Stevenson, J.R., Tanoy, A., Villarante, P., Morissens, P., 2007. The equity and poverty impacts of aquaculture: Insights from the Philippines. Development Policy Review, 25 (4), 495516

Smith M.D., Roheim, C.A., Crowder, L.B., Halpern, B.S., Turnipseed, M., Anderson, J.L., Asche, F., Bourillón, L., Guttormsen, A.G., Khan, A., Liguori, L.A., McNevin, A., O'Connor, M.I., Squires, D., Tyedmers, P., Brownstein, C., Carden, K., Klinger, D.H., Sagarin, R., Selkoe, K.A., 2010. Sustainability and global seafood. Science. 327, 784-786.

Stead, S.M., 2005. A comparative analysis of two forms of stakeholder participation in European aquaculture governance: Self-regulation and Integrated Coastal Zone Management, in: Gray, T.S. (Ed.), Participation in fisheries governance, Springer, pp. 179-192.

Stonich, S.C., Bailey, C., 2000. Resisting the Blue Revolution: Contending Coalitions Surrounding Industrial Shrimp Farming. Human Organization. 59(1), 23-26.

Subasinghe, R.P., Arthur, J.R., Bartley, D.M., De Silva, S.S., Halwart, M., Hishamunda, N., Mohan, C.V., Sorgeloos, P., 2012. Proceedings of the Global Conference on Aquaculture 2010: Farming the Waters for People and Food. FAO, Rome, NACA, Bangkok.

Toufique, K.A. and Belton B., 2014. Is Aquaculture Pro-Poor? Empirical Evidence of Impacts on Fish Consumption in Bangladesh. World Development 64, 609-620.

Toufique, K.A., Gregory, R., 2008. Common waters and private lands: distributional impacts of floodplain aquaculture in Bangladesh. Food Policy. 33, 587-594.

Troell, M., Naylor, R.L., Metian, M., Beveridge, M., Tyedmers, P.H., Folke, C.,Arrow, K.J., Barrett, S., Crépin, A.-S., Ehrlich, P.R., Gren, Å., Kautsky, N. Levin, S.A., Nyborg, K., Österblom, H., Polasky, S., Scheffer, M., Walker, B.H., Xepapadeas, T., de Zeeuw, A., 2014. Does aquaculture add resilience to the global food system? PNAS Early edition.

Turner RA, Fitzsimmons C, Forster J, Peterson A, Mahon R, and Stead SM. 2014. Measuring good governance for complex ecosystems: Perceptions of coral reef-dependent communities in the Caribbean. Global Environmental Change, In Press. 
Varela, J., 2001. The Human Rights Consequences of inequitable Trade and Development Expansion: The Abuse of Law and Community Rights in The Gulf of Fonseca, Honduras, in: Barnhizer, D. (Ed.), Effective Strategies for Protecting Human Rights: Prevention and intervention, trade and education. Ashgate, Dartmouth, p. 155.

Veuthey, S., Gerber, J.F., 2012. Accumulation by dispossession in coastal Ecuador: Shrimp farming, local resistance and the gender structure of mobilizations. Global Environ. Change. 22, 611-622.

Williams, M.J., Bell, J.D., Gupta, M.V., Dey, M., Ahmed, M., Prein, M., Child, S., Gardiner, P.R., Brummett, R., Jamu, D., 2000. Responsible aquaculture can aid food problems. Nature. 406, 73.

Williams, S.B., Hochet-Kibongui, A.M., Nauen, C.E., 2005. Gender, fisheries and aquaculture: Social capital and knowledge for the transition towards sustainable use of aquatic ecosystems. ACP-EU Fish. Res. Rep. No. 16.

World Bank, 2012. World Development Report 2013: Jobs. Washington, DC: World Bank.

WorldFish, 2011. Policy Brief 2011-07.

Zurek, M.B., Henrichs, T., 2007. Linking scenarios across geographical scales in international environmental assessments. Technological Forecasting \& Social Change. 74(8), 1282-1295.

\section{Web References}

http://bantryblog.wordpress.com/ (access on October $30^{\text {th }} 2013$ )

http://www.fao.org/fsnforum/cfs-hlpe/fisheries-and-aquaculture (access on September 13th 2013) 


\section{Figure Captions}

Figure 1. An example of different aquaculture in different social scenarios and at different scales of production in long-line mussel production, which illustrates the varied contexts of this activity for e.g. employment and degree of technology. A) Local fishermen harvesting green mussels (Perna viridis) in Chumphon Bay/Thailand (photo courtesy: Michael Vakily, WorldFish Center (formerly ICLARM) B) the automated offshore Reynaert-Versluys pontoon mussel collector (Mytilus edulis) in Belgium (photo courtesy: Willy Versluys).

Figure 2. [A) An integrated 4-step approach for aquaculture systems analysis and B) A dynamic representation of the upper figure which includes the 4-step processes from design to implementation by path. S1 is the time of initial assessment followed by a feedback loop (green dot). S2, S3, etc. indicate the iterative process through the 4-step framework followed by the respective feedback loops over time. The convergent spiral illustrates the social adaptation leading over the course of time to meet the objectives targeted. 


\section{ACCEPTED MANUSCRIPT}

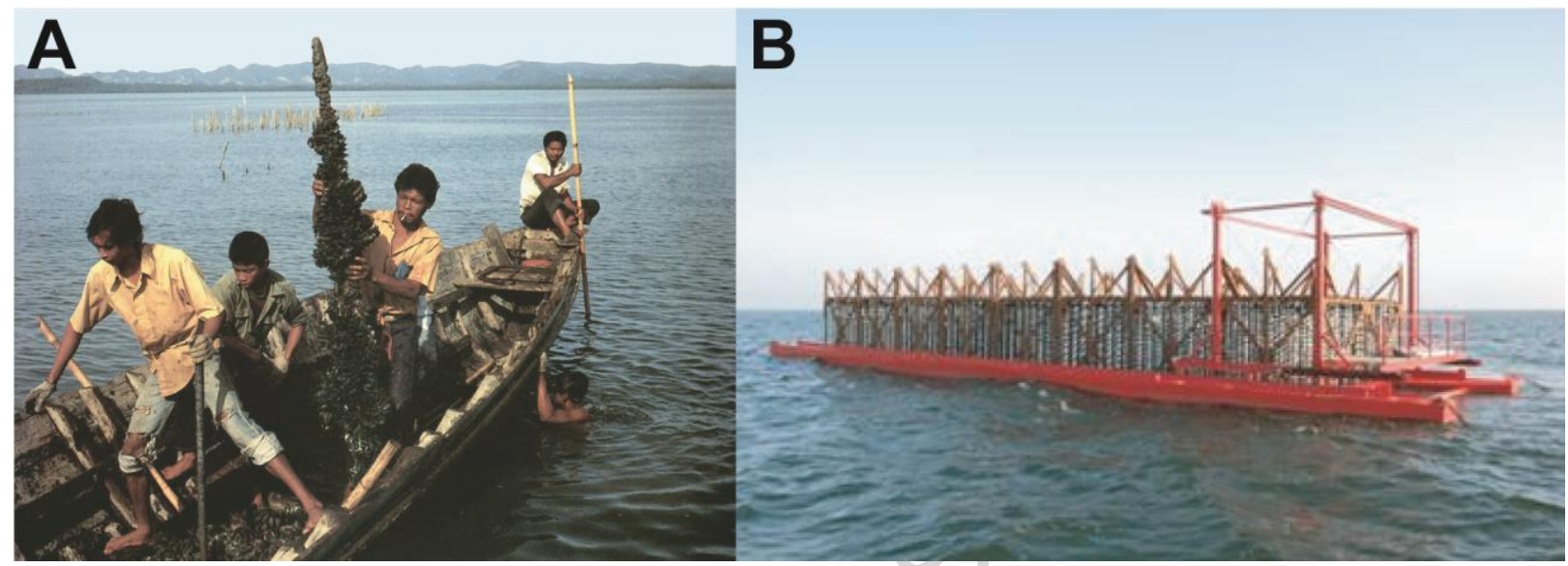

Figure 1 


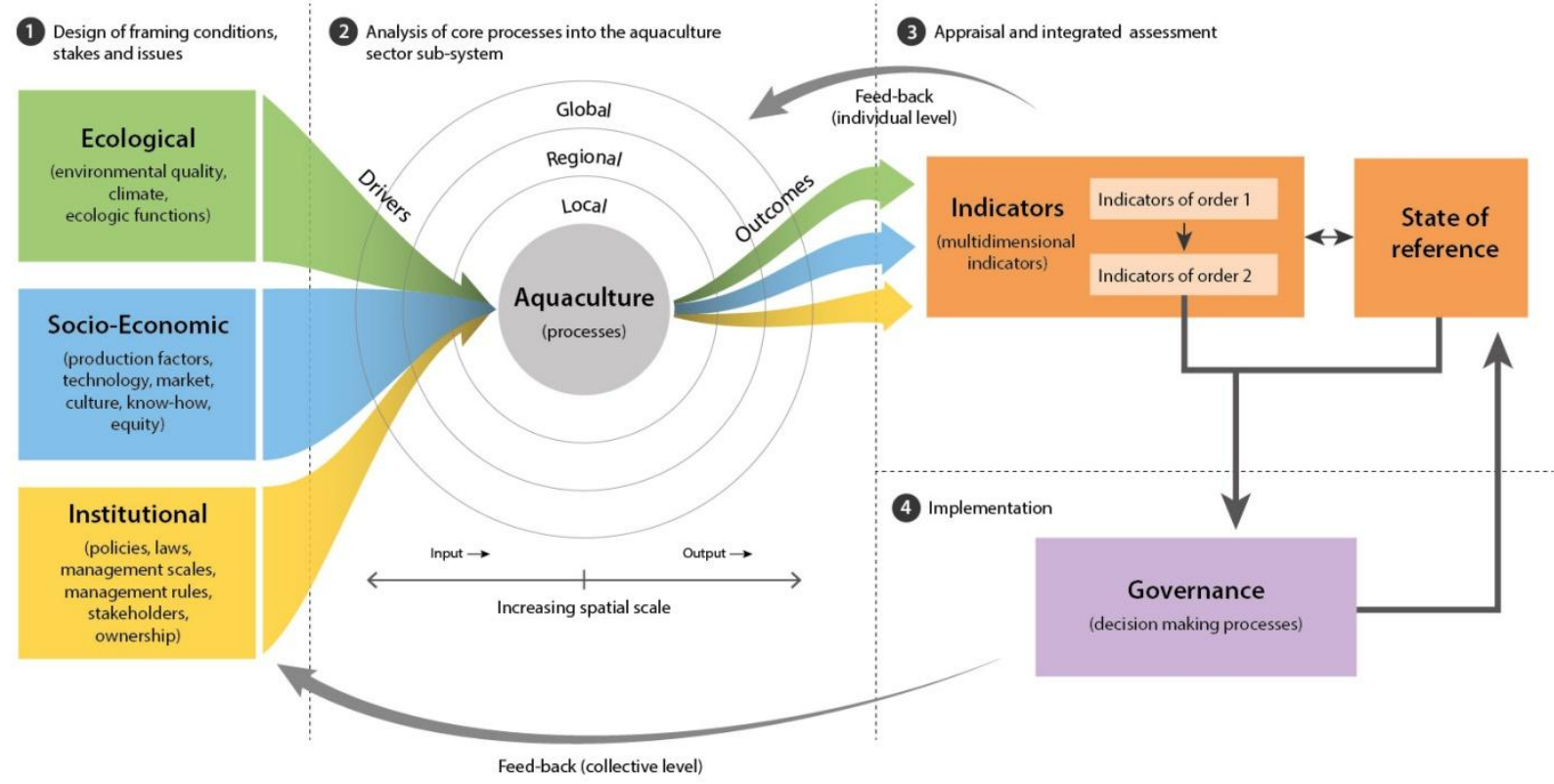

Figure 2a 


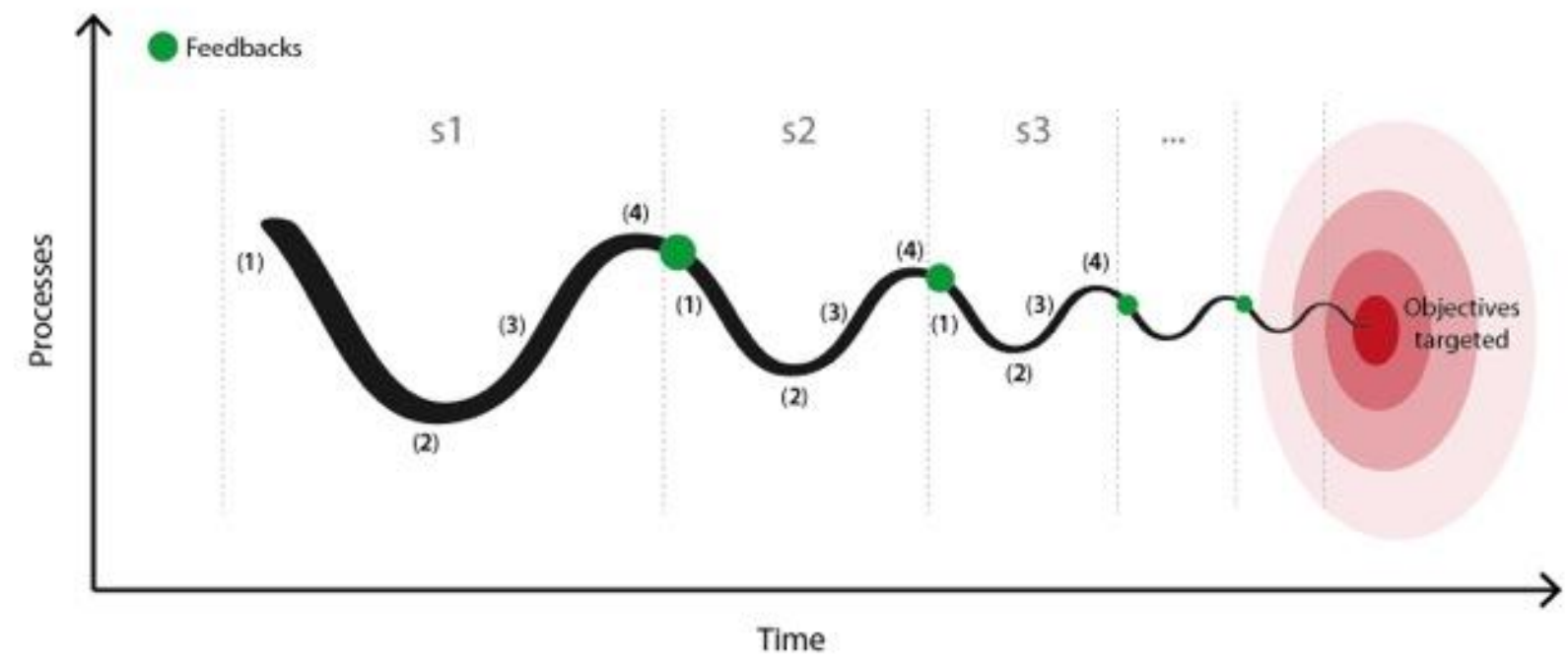

Figure 2b 